KeMAS 16 (3) (2021) 452-459
Jittp:/journal.unnes.ac.id/nju/index.php/kemas

\title{
Risk of Pesticide Exposure on Impaired Level of Intelligence (IQ) of Children
}

Ari Suwondo ${ }^{1 凶}$, Melyana Nurul Widyawati ${ }^{2}$, Bina kurniawan ${ }^{1}$, Endah Kumala Dewi ${ }^{1}$

${ }^{1}$ Occupational Health Safety Department, Faculty of Public Health, Diponegoro University

${ }^{2}$ Master of Applied Midwifery, Postgraduate Program, Poltekkes Kemenkes Semarang

Article Info

Article History:

Submitted February 2021

Accepted February 2021

Published March 2021

Keywords:

Elementary schooler;

Pesticide exposure; Level of

intelligence.

DOI

https://doi.org/10.15294/

kemas.v16i3.29232

\begin{abstract}
The shallot cropping pattern applied by farmers in the village of Pasir Demak is very likely to cause pollution. Pesticide contamination in pregnant women in the first trimester (3 months) can result in fetal death, low birth weight, and impaired intelligence (IQ). Preliminary research conducted in 2016 found that elementary schooler who came from Pasir Village, Demak had low learning achievement. It was an observational study with a cross-sectional approach; the respondents were Elementary Schooler grades 4, 5, and 6 (107 people) and the mothers of the students (107 people). Thus, the total respondents were 214 people. The IQ assessment instrument used the SPM and CPM instruments. The level of pesticide poisoning from the mother was to measure blood Cholin Esterase levels using a tintometer, the data were then statistically analyzed using Chi Square and Odd Ratio for risk factors. There were significant differences on the level of intelligence of children including the planting system $p=0.002$; room area $p=0.047$; ventilation area $\mathrm{p}=0.041$; type of pesticide $\mathrm{p}=0.001$; spraying before harvest $\mathrm{p}=0.007$; spraying after harvest $\mathrm{p}=0.008$; storage place for crop yields $\mathrm{p}=0.039$, while the variables that did not show significant difference were the playing environment $\mathrm{p}=0.848$; gestational age $\mathrm{p}=0.190$; contact to pesticides $\mathrm{p}=0.105$ and age $\mathrm{p}=0.418$. Pesticide contamination in pregnant women in the 1st trimester which the time to process formation and development of the brain in the Temporal lobe and Frontal lobe will experience impaired learning and memory (IQ). Keywords : Elementary schooler; Pesticide exposure; Level of intelligence.
\end{abstract}

\section{Introduction}

Organophosphates, which kill pests by attacking the nervous system, have previously been linked to developmental delays and attention problems in children exposed during pregnancy (Grandjean et al., 2006). Currently, researchers in two different sites found that children's IQ tended to decrease proportionally because of exposure to pesticides during pregnancy. This case can have a further impact on decreased children's performance, making them a generation that is not smart and productive and eventually, the contribution of this group to national development declined (Handal et al., 2007).
A study included hundreds of Latin mothers and children in California's Salinas Valley, a commercial farming center. Many women were gardeners or had family members who worked in the agricultural fields. When these women became pregnant, researchers tested their urine for several organophosphate standard chemical products using an exposure measurement tool (Starks et al., 2012). As a result, pregnant women who were exposed to the highest levels of pesticides had children at the age of 7 years with an IQ of seven points lower compared to the mean IQ of children with the same age whose mothers were shallow exposure to pesticides (the mean was 100) (Sánchez Lizardi et al., 2008). 
Organophosphates that 'pass' from the mother to the fetus through the placenta and umbilical cord can be more damaging to fetal development than those directly exposed to children (who they have been born) 5 Researchers describe that similar trends can also be found outside the agricultural community. Pregnant women outside the farming community can also be exposed to high pesticides from the fruits and vegetables they eat. Pesticide exposure to the first trimester pregnant women can interfere with the fetal brain's development, even with a moderate amount. A study conducted in the United States stated that this disorder could affect the intelligence of babies after birth (Bradman et al., 2011, 2015).

A study conducted by the Proceedings of the National Academy of Sciences observed 369 pregnant women exposed to the chlorpyrifos pesticide $(\mathrm{CPF})$, widely used in anti-pest drugs in agriculture and public spaces. This study is a continuation of United States regulations that prohibit CPF substances in housing, although this substance is still used worldwide in agriculture(V. Rauh et al., 2015; Woodruff et al., 2011). Researchers compared the brain health condition of 20 children aged 5-11 years whose mothers, according to test results, were exposed to relatively high CPF level. The study found significant abnormalities in these children's brain structures compared to 20 children whose mothers were not exposed to high CPF levels (Appleton et al., 2016; V. A. Rauh et al., 2012). However, all women from the study were exposed to CPF substances at normal levels, limiting exposure by US regulations regarding exposure to this substance. This problem indicates that CPF exposure in low to moderate amounts can also pose a significant risk to the development of a child's brain (V. A. Rauh et al., 2012, 2015).

Pasir Village in Mijen Subdistrict, Demak District, is one area with a large agricultural area. The main occupation of the community in Pasir Village is a farmer. The main commodity in this village is shallot, and the shallot plants use many pesticides. Based on the initial survey conducted in the Pasir Village, most residents' houses coincide, so each house's space and ventilation were minimal. Many people stored pesticides around the house, and there were some pesticides stored in open spaces so that pesticides could contaminate family members. This pesticide pollution would then affect the growth and development of children. If a pregnant woman in the first trimester $(<3$ months) stays in a house exposed to pesticides for 24 hours, she can be poisoned, marked by a decrease in cholinesterase levels in the blood than the standard limit. Poisoning is divided into 3, namely: A decrease in cholinesterase levels to be $75 \%-50 \%$ off standard limit: Mild Poisoning; A decrease in cholinesterase levels to be $50 \%-25 \%$ of standard limit: Moderate poisoning; A decrease in cholinesterase levels to be $<25 \%$ of the standard limit: Severe poisoning. The mechanism of pesticide poisoning in pregnant women is that substances in contact with pregnant women penetrate the placental barrier in the uterus, and harmful substances will poison the fetus to damage the brain and interfere with the growth of the baby at birth. This problem will cause delayed children's growth and development.

\section{Method}

The study method used was quantitative with cross sectional design where the variables to be studied were taken at the same time (Sastroasmoro \& Ismael, 2011). Dependent Variable was Level of Intelligence (IQ) while the Independent Variables were Type of Pesticides, Pre-Harvest Spraying, Post-Harvest Spraying, Planting System, Storage Place for Crop Yields, Playing Environment, Bedroom Area, Ventilation Area, Gestasional Age, Contact to Pesticide, Age. Population is the whole study object of the objects under study (Sugiyono, 2017). The study population were all students of State Elementary School 1 Pasir in grades 4.5, and 6 (107 people) and the mothers of the students of State Elementary School 1 Pasir in grades 4.5 , and 6 (107 people). Thus, the total respondents taken were as many as 214 people.

Research instrument using Standart Progressive Matrices (SPM) and Coloured Progressive Matrices (CPM) are tools or instruments used to measure the intelligence levels in school-aged children. CPM is used for children aged $<11$ years while SPM is used for children aged $>11$ years. This instrument 
has been validated and reliable.(Abdel-Khalek, 2005; Bildiren, 2017). The outputs of these instruments are grades consisting of 1 to 5 with different value ranges between SPM and CPM. Bivariate analysis used Chi Square test and Odd Ratio was used to determine the size of risk factors on the intelligence level children.

\section{Result and Discussion}

Pasir Village is the westernmost village in Mijen Subdistrict is bordered by the area Wedung Sub-district, Demak District. Desa Pasir Village had a population of 8854 people with 4515 men and 4339 women in January 2016, making Pasir village the most populous village in the Mijen District area. Of the many inhabitants, most of the people of Pasir Village have a livelihood as farmers with the largest shallot, red chilies, and other crops. As the largest producer of shallot in the Demak District, the crop yields were distributed to other cities such as Jakarta, Tuban, Surabaya, and even Kalimantan and its surroundings.

Income from shallot harvest in Pasir Village makes this village ranked No. 2 as the largest shallot producer after Brebes District. Farmers in Pasir Village initially hired or took expert farmers from Brebes District to teach about planting shallots, but currently, the people of Pasir Village have cultivated their fields. On average, farmers in Pasir village use more than two pesticides, and they often used pesticides such as Amate, Arjuna, and Regent. The spraying mechanism used by farmers is correct by following the wind's direction, but most farmers still use trenches in their planting system. The Trenching system can increase the likelihood of pesticide exposure. Harvesting was usually done two times a year. Farmers used to spray pesticides before and after the harvest season to get rid of pests.

Table 1. Relationship between Independent Variables and Dependent Variable

\begin{tabular}{|c|c|c|c|c|c|c|c|c|}
\hline \multirow{3}{*}{\multicolumn{2}{|c|}{ Independent Variables }} & \multicolumn{4}{|c|}{$\begin{array}{l}\text { Dependent Variable } \\
\text { Level of Intelligence }\end{array}$} & \multirow{2}{*}{\multicolumn{2}{|c|}{ Total }} & \multirow[t]{3}{*}{ p-value } \\
\hline & & \multicolumn{2}{|c|}{ Less } & \multicolumn{2}{|c|}{ Good } & & & \\
\hline & & $\mathrm{f}$ & $\%$ & $\mathrm{f}$ & $\%$ & f & $\%$ & \\
\hline \multirow{2}{*}{ Types of Pesticides } & $>2$ Types & 13 & 32.5 & 27 & 67.5 & 40 & 100.0 & \multirow{2}{*}{0.001} \\
\hline & $\leq 2$ Types & 5 & 7.5 & 62 & 92.5 & 67 & 100.0 & \\
\hline \multirow{2}{*}{$\begin{array}{l}\text { Pre-Harvest } \\
\text { Spraying }\end{array}$} & Yes & 15 & 25.9 & 43 & 74.1 & 58 & 100.0 & \multirow{2}{*}{0.007} \\
\hline & No & 3 & 6.1 & 46 & 93.9 & 49 & 100.0 & \\
\hline \multirow{2}{*}{$\begin{array}{l}\text { Post-Harvest } \\
\text { Spraying }\end{array}$} & Yes & 9 & 33.3 & 18 & 66.7 & 27 & 100.0 & \multirow{2}{*}{0.008} \\
\hline & No & 9 & 11.3 & 71 & 88.8 & 80 & 100.0 & \\
\hline \multirow{2}{*}{ Planting System } & Trench & 13 & 31.0 & 29 & 69.0 & 42 & 100.0 & \multirow{2}{*}{0.002} \\
\hline & Not a Trench & 5 & 7.7 & 60 & 92.3 & 65 & 100.0 & \\
\hline \multirow{2}{*}{ Storage } & Inside House & 2 & 5.9 & 32 & 94.1 & 34 & 100.0 & \multirow{2}{*}{0.0039} \\
\hline & Outside House & 16 & 21.9 & 57 & 78.1 & 73 & 100.0 & \\
\hline \multirow{2}{*}{$\begin{array}{l}\text { Playing } \\
\text { Environment }\end{array}$} & Former Rice Field & 4 & 18.2 & 18 & 81.8 & 22 & 100.0 & \multirow{2}{*}{0.848} \\
\hline & Not Former Rice Field & 14 & 16.5 & 71 & 83.5 & 85 & 100.0 & \\
\hline \multirow{2}{*}{ Bedroom Area } & Less & 11 & 25.6 & 32 & 74.4 & 43 & 100.0 & \multirow{2}{*}{0.047} \\
\hline & Good & 7 & 10.9 & 57 & 89.1 & 64 & 100.0 & \\
\hline \multirow{2}{*}{ Ventilation Area } & Less & 12 & 25.0 & 36 & 75.0 & 48 & 100.0 & \multirow{2}{*}{0.041} \\
\hline & Good & 6 & 10.2 & 53 & 89.8 & 59 & 100.0 & \\
\hline \multirow{2}{*}{ Gestasional Age } & $\leq 3$ Months & 9 & 23.1 & 30 & 76.9 & 39 & 100.0 & \multirow{2}{*}{0.190} \\
\hline & >3 Months & 9 & 13.2 & 59 & 86.8 & 68 & 100.0 & \\
\hline \multirow{2}{*}{ Pesticide Contact } & Yes & 4 & 33.3 & 8 & 66.7 & 12 & 100.0 & \multirow{2}{*}{0.105} \\
\hline & No & 14 & 14.7 & 81 & 85.3 & 95 & 100.0 & \\
\hline \multirow{2}{*}{ Age } & $<11$ Years & 11 & 14.9 & 63 & 85.1 & 74 & 100.0 & \multirow{2}{*}{0.418} \\
\hline & $\geq 11$ Years & 7 & 21.2 & 26 & 78.8 & 33 & 100.0 & \\
\hline
\end{tabular}


Table 1 describe that the Type of Pesticide variable shows that 13 (32.5\%) respondents used $>2$ types of pesticide and 5 $(7.5 \%)$ respondents used $\leq 2$ types of pesticide. The analysis results obtained a p-value of 0.001 at a significance level of 5\%, which meant there was a relationship between the type of pesticide and the level of intelligence of students in grades 4, 5, 6 of State Elementary School 1 Pasir. The Pre-Harvest Spraying variable shows that among respondents who had less intelligence, 15 (25.9\%) respondents performed pre-harvest spraying and $3(6.1 \%)$ respondents did not perform pre-harvest spraying. The analysis results obtained a p-value of 0.007 at a significance level of 5\%, which meant that there was a relationship between pre-harvest spraying and the level of intelligence of students in grades 4, 5, 6 of State Elementary School 1 Pasir.

The Post-Harvest Spraying variable shows that among respondents who had less intelligence, 9 (33.3\%) respondents performed post-harvest spraying and $9(11.3 \%)$ respondents did not perform post- harvest spraying. The analysis results obtained a p-value of 0.008 at a significance level of $5 \%$, which meant that there was a relationship between post-harvest spraying and the level of intelligence of students in grades 4, 5, 6 of State Elementary School 1 Pasir. The Planting System variable explain that among respondents who had less intelligence, $13(31.0 \%)$ respondents used trenches in the plating system and $5(7.7 \%)$ respondents did not use trenches in the plating system. The analysis results obtained a p-value of 0.002 at a significance level of $5 \%$, which meant that there was a relationship between the planting system and the level of intelligence of students in grades 4, 5, 6 of State Elementary School 1 Pasir.

The Storage variable shows that among respondents who had less intelligence, 2 (5.9\%) respondents stored the crop yields inside the house and 16 (21.9\%) respondents stored the crop yields outside the house. The analysis results obtained a p-value of 0.039 at a significance level of $5 \%$, which meant that there was a relationship between the storage of crops and the level of intelligence of students in grades 4, 5, 6 of State Elementary School 1 Pasir. The
Playing Environment variable indicates that respondents who had less intelligence, 4 (18.2\%) respondents had playing environment in the former rice field and 14 (16.5\%) respondents had playing environment not in the former rice field. The analysis results obtained a p-value of 0.848 at a significance level of $5 \%$ which meant that there was no relationship between the playing environment and the level of intelligence of students in grades 4, 5, 6 of State Elementary School 1 Pasir.

The Bedroom Area variable indicates that among respondents who had less intelligence, $11(25.6 \%)$ respondents had less bedroom area and 7 (10.9\%) respondents had good bedroom area. The analysis results obtained a p-value of 0.047 at a significance level of 5\%, which meant that there was a relationship between the bedroom area and the level of intelligence of students in grades 4, 5, 6 of State Elementary School 1 Pasir. The Ventilation Area variable shows that among respondents who had less intelligence, 12 (25.0\%) respondents had less ventilation area and $6(10.2 \%)$ respondents had good ventilation area. The analysis results obtained a p-value of 0.041 at a significance level of $5 \%$, which meant that there was a relationship between ventilation area and the level of intelligence of students in grades 4, 5, 6 of State Elementary School 1 Pasir.

The Gestasional Age variable shows that among respondents who had less intelligence, 9 (23.1\%) respondents were exposed to pesticiddes in the gestational age of $\leq 3$ months and $9(13.2 \%)$ respondents were exposed to pesticiddes in the gestational age of $>3$ Months. The analysis results obtained a p-value of 0.190 at a significance level of $5 \%$ which meant that there was no relationship between maternal gestational age and the level of intelligence of students in grades 4, 5, 6 of State Elementary School 1 Pasir. The Pesticide Contact variable can be seen that among respondents who had less intelligence, 4 (33.3\%) respondents had a contact to pesticide and $14(14.7 \%)$ respondents had no contact to pesticide. The analysis results obtained a p-value of 0.105 at a significance level of $5 \%$, which meant that there was no relationship between contact pesticides and the level of intelligence of students in grades 4, 5, 6 of State Elementary School 1 Pasir. The Age 
variable explain that among respondents who had less intelligence, 11 (14.9\%) responds aged $>11$ years and $7(21.2 \%)$ respondents aged $\leq 11$ years. The analysis results obtained a p-value of 0.418 at a significance level of $5 \%$, which meant that there was no relationship between age and the level of intelligence of students in grades 4 , 5, 6 of State Elementary School 1 Pasir

Farmers who plant crops that are vulnerable to pests always depend on pesticides in plants' care, starting from planting, growing, and harvesting. Based on their predecessors' experience, they will emulate farming behavior, which is considered quite successful, and they are afraid to change to cropping patterns and crop maintenance, which they think will have a destructive impact on crop yields. Shallots farmers in Pasir Village have received counseling both from the Agriculture Department's agricultural educator and from the health counselor from the community health center about the health hazards of pesticides both for the spraying operator and for families who participate in managing the shallot planting period.

In handling the protection of shallots from the planting, growing, and harvesting, farmers use several types of pesticides such as organophosphate, carbamate pesticides, and even suspected that some farmers use organochlorine pesticides are very toxic and difficult to degrade in nature. (Jayaraj et al., 2016). In addition to these pesticides, it is still possible to use fungicides (plant fungus killers), which are toxic to the human body (Rouabhi, 2010). OPs (organophosphate) act as an inhibitor of the acetylcholinesterase (AChE) enzyme, which targetting several molecules, such as hormones; neurotransmitters; neurotrophic factors; enzymes related to the metabolism of beta-amyloid protein as well as inflammatory (Ghimire, 2016). OPs also affected the thyroid hormone. Thyroid hormone is known as a growth hormone, especially on brain development, which affects neuron and brain development. The similarity in the chemical structure of pesticides with thyroid hormones (TH-r) in target cells, it interferes with the process of thyroid hormone synthesis. TH synthesis in the thyroid colloid requires Iodine, which circulates as Iodine ion.
In the thyroid gland, iodine is combine with the amino acid tyrosine to produce thyroxine ( T4 ) or triiodothyronine ( T3 ). Synthesis of THs ( T4 \& T3 ) is tighly controlled by the HPT-axis, disruption at any of the multiple levels along the Hypothalamus-Pytuitary-Thyroid axis is causing the disruption of THs secretion. The Hypothalamus produces thyrotropin releasing hormone ( TRH ) which triggers production of thyroid stimulating hormone ( TSH ) by anterior Pituitary, TSH stimulate iodine uptake. Pesticides like thyroid hormone ( TH-r ), it will affect THs production (Lacasaña et al., 2010). The OPs as a free radical will damage the cell wall through lipid peroxidation so that all of the organelle cells would affect and could not act properly that will end by cell death. Because of that process, mitosis of brain cells will stop and will affect the development of the brain (Mishra et al., 2012).

During the shallot plant maintenance, the farmer's family members, such as his wife and children, often assist in crop maintenance. Immensely during harvest, his wife and children also help clean the shallot from attached soil or clean the shallot from pests that do not die during pesticide spraying. The process of pesticide spraying carried out by shallots farmers in Pasir Village in Mijen subdistrict, Demak, is the same as that carried out by shallots farmers in Brebes. This process is because, at the beginning of their planting efforts, they contracted farmers in Brebes to protect crops from pests. The pesticide spraying farmers from Brebes applied the spraying pattern they used to do in Brebes, which they said as relatively safe, and the results were quite effective in protecting plants from pests.

The process of pesticide spraying that has been practiced until now is a spray pattern of 2-3 times a week, even more spraying during the rainy season, and by using more than two types of pesticides. Farmers did not only carry out spraying during the growing process of shallots but also before harvest and after harvest to protect the harvest during storage. They prepared pesticides in the house. During the pesticide mixing process and when spraying, they rarely used complete personal protective equipment to ensure they were exposed to pesticides. This practice may cause 
serious health problems to depend on the dose of exposure and duration of exposure. Health effects of acute and chronic on pesticide spraying farmers have been widely studied, but the impact of pesticides on people who help the processes from planting to harvest and those who live in the house wherein the shallot yields are stored have not been widely studied (Damalas \& Eleftherohorinos, 2011). The spraying pattern that was carried out during the maintenance of shallots, before harvest and after harvest, will cause the crop yields to contain a large number of pesticide residues, and in summer, the pesticide residues will evaporate and spread throughout the room in the house so that people who live in it will be exposed to these pesticides.

Risk factors related to the level of intelligence of children (OD Ratio) ranked from the factor with the most significant effect were: the type of pesticides (5.970), Planting system (5.379), Pre-harvest spraying (5.349), Post-harvest spraying (3.944), Area of house ventilation (2.944), Bedroom area (2.799) and storage place for crop yields (0.223). Variables that did not affect children's level of intelligence were playing environment $\mathrm{p}=0.848$; gestational age $\mathrm{p}=0.190$; contact to pesticides $\mathrm{p}=0.0105$ and age $\mathrm{p}=0.418$.

The type of pesticide was the most significant risk factor associated with the level of intelligence. This result was very relevant because farmers who applied pesticides to protect shallot plants from pests did not only use one type of pesticide, but they mixed several types from organophosphate groups or the type of carbamate. It is even possible to add organochlorine pesticides, which are very toxic and persistent in the environment (Van Dyk \& Pletschke, 2011). It was coupled with a planting system trenches, pre-harvest, and post-harvest spraying behavior operand and the storage of crop yields inside around the house. The house condition that did not meet the requirements of a healthy house regarding the ventilation area and bedroom area, it could be assumed that when there was the evaporation of pesticides on shallots, it would pollute the entire room occupants of the house (Aktar et al., 2009; Van Dyk \& Pletschke, 2011).
Pesticide pollution in pregnant women in the first trimester will affect the fetus in the uterus by developing fetal growth at that time (Takser et al., 2004). Theoretically, fetal development in the three months gestation is in the period of the nerve cell and brain development, so that pesticide contamination during this period can affect the neurological and brain health of the fetus, which was examined in this study as the level of intelligence or IQ of children. The effect of pesticide poisoning during pregnancy will fail to form neurons (nerve cells) that may lead to neurogenesis, angiogenesis, and synaptogenesis. The failure of neurons' formation will cause symptoms by the time exposure and the part of the brain, in the formation or development stage at that time.

Learning and remembering process disorder primarily occurs when the brain's formation and development in the Temporalis and Frontalis lobes experience interference that is very likely to occur when the fetus is still in the uterus. Pesticides are known to penetrate the brain barrier of the fetus which come from mothers exposed to pesticides, and these pesticides have the nature of free radicals that severely damage the nerve cell membrane walls so that many nerve cells fail to grow, and this condition results in the decreased normal function of cerebrum area. Damage in other parts of the brain is possible considering that the process of growth and development of the brain co-occur by the gestational age and brain development process itself

\section{Conclusion}

Onion farmers in the Pasir village of Demak Regency who apply cropping patterns and crop patterns with excessive use of pesticides and mixing several types of pesticides, will definitely cause poisoning effects both on the farmers themselves and on their families. This is reinforced by the storage of crops in the house and the environmental conditions of the house which are not suitable for health conditions. When it is summer, the pesticides attached to shallots will evaporate and affect all residents of the house. If at that time the occupants of the house were pregnant women in the 1st trimester (less than 3 months 
of pregnancy), at this time there was a process of formation and development of the brain in the Temporal lobe and Frontal lobe.

\section{References}

Abdel-Khalek, A.M., 2005. Reliability and Factorial Validity of the Standard Progressive Matrices among Kuwaiti Children Ages 8 to 15 Years. Perceptual and Motor Skills, 101(2), pp.409412.

Aktar, W., Sengupta, D., \& Chowdhury, A., 2009. Impact of Pesticides Use in Agriculture: Their Benefits and Hazards. Interdisciplinary Toxicology, 2(1).

Appleton, A.A., Holdsworth, E.A., \& Kubzansky, L.D., 2016. A Systematic Review of the Interplay Between Social Determinants and Environmental Exposures for Early-Life Outcomes. In Current Environmental Health Reports, 3(3).

Bildiren, A., 2017. Reliability and Validity Study for the Coloured Progressive Matrices Test between the Ages of 3-9 for Determining Gifted Children in the Pre-School Period. Journal of Education and Training Studies, 5(11), pp.13.

Bradman, A., Castorina, R., Barr, D.B., Chevrier, J., Harnly, M.E., Eisen, E.A., McKone, T.E., Harley, K., Holland, N., \& Eskenazi, B., 2011. Determinants of Organophosphorus Pesticide Urinary Metabolite Levels in Young Children Living in an Agricultural Community. International Journal of Environmental Research and Public Health, 8(4).

Bradman, A., Quirós-Alcalá, L., Castorina, R., Schall, R.A., Camacho, J., Holland, N.T., Barr, D.B., \& Eskenazi, B., 2015. Effect of Organic Diet Intervention on Pesticide Exposures in Young Children Living in Low-income Urban and Agricultural Communities. Environmental Health Perspectives, 123(10).

Damalas, C.A., \& Eleftherohorinos, I.G., 2011. Pesticide Exposure, Safety Issues, and Risk Assessment Indicators. International Journal of Environmental Research and Public Health, 8(5).

Ghimire, R., 2016. Management of Organophosphorous Poisoning. Journal of Nepal Health Research Council, 14, pp.131138.

Grandjean, P., Raul, H., Barr, D.B., \& Debes, F., 2006. Pesticide Exposure and Stunting as Independent Predictors of Neurobehavioral Deficits in Ecuadorian School Children.
Pediatrics, 117(3).

Handal, A.J., Lozoff, B., Breilh, J., \& Harlow, S.D., 2007. Neurobehavioral Development in Children with Potential Exposure to Pesticides. Epidemiology, 18(3).

Jayaraj, R., Megha, P., \& Sreedev, P., 2016. Review Article. Organochlorine Pesticides, Their Toxic Effects on Living Organisms and Their Fate in the Environment. In Interdisciplinary Toxicology, 9(3-4).

Lacasaña, M., López-Flores, I., Rodríguez-Barranco, M., Aguilar-Garduño, C., Blanco-Muñoz, J., Pérez-Méndez, O., Gamboa, R., Bassol, S., \& Cebrian, M.E., 2010. Association between Organophosphate Pesticides Exposure and Thyroid Hormones in Floriculture Workers. Toxicology and Applied Pharmacology, 243(1), pp.19-26.

Mishra, D.B.P., Badade, Z., \& Rastogi, S.K., 2012. Free Radical and Antioxidant Status Among Organophosphate Pesticide Exposed Sprayers. Indian Journal of Forensic Medicine and Toxicology, 6, pp.13-16.

Rauh, V.A., Garcia, W.E., Whyatt, R.M., Horton, M.K., Barr, D.B., \& Louis, E.D., 2015. Prenatal Exposure to the Organophosphate Pesticide Chlorpyrifos and Childhood Tremor. NeuroToxicology, 2015.

Rauh, V.A., Perera, F.P., Horton, M.K., Whyatt, R.M., Bansal, R., Hao, X., Liu, J., Barr, D.B., Slotkin, T.A., \& Peterson, B.S., 2012. Brain Anomalies in Children Exposed Prenatally to a Common Organophosphate Pesticide. Proceedings of the National Academy of Sciences of the United States of America, 109(20).

Rauh, V., Arunajadai, S., Horton, M., Perera, F., Hoepner, L., Barr, D.B., \& Whyatt, R., 2015. Seven-year Neurodevelopmental Scores and Prenatal Exposure to Chlorpyrifos, A Common Agricultural Pesticide. Everyday Environmental Toxins: Childrens Exposure Risks, 119(8).

Rouabhi, R., 2010. Introduction and Toxicology of Fungicides (pp. 363-382).

Sánchez Lizardi, P., O’Rourke, M.K., \& Morris, R.J., 2008. The Effects of Organophosphate Pesticide Exposure on Hispanic Children's Cognitive and Behavioral Functioning. Journal of Pediatric Psychology, 33(1).

Sastroasmoro, S., \& Ismael, S., 2011. Dasar-dasar Metodologi Penelitian Klinis (4th ed.). Sagung Seto.

Starks, S.E., Gerr, F., Kamel, F., Lynch, C.F., Jones, M.P., Alavanja, M.C., Sandler, D.P., \& Hoppin, J.A., 2012. Neurobehavioral 
Function and Organophosphate Insecticide Use Among Pesticide Applicators in the Agricultural Health Study. Neurotoxicology and Teratology, 34(1).

Sugiyono., 2017. Metode Penelitian Pendidikan Pendekatan Kuantitatif, Kualitatif, dan R\&D.

Takser, L., Lafond, J., Bouchard, M., St-Amour, G., \& Mergler, D., 2004. Manganese Levels During Pregnancy and at Birth: Relation to Environmental Factors and Smoking in a Southwest Quebec population.
Environmental Research, 69(3).

Van Dyk, J.S., \& Pletschke, B., 2011. Review on the Use of Enzymes for the Detection of Organochlorine, Organophosphate and Carbamate Pesticides in the Environment. Chemosphere, 82(3).

Woodruff, T.J., Zota, A.R., \& Schwartz, J.M., 2011. Environmental Chemicals in Pregnant Women in the United States: NHANES 20032004. Environmental Health Perspectives, 119(6). 